\title{
Financial Literacy Model at Micro Small Medium Entreprise (MSMEs)
}

\author{
${ }^{1}$ SRI WIDIYATI, ${ }^{2}$ EDI WIJAYANTO, ${ }^{3}$ PRIHATININGSIH \\ 1,2,3 Jurusan Akuntansi,Politeknik Negeri Semarang, Jl. Prof.Soedarto SH,Tembalang Semarang 50275 \\ surel: ${ }^{1}$ wiwidsoemodipoero@yahoo.co.id; ${ }^{2}$ ediwiyanto@gmail.com; 3atin_weis@yahoo.com
}

\begin{abstract}
Financial literacy level of MSMEs (Micro, Small, and Medium Enterprises) is only $15.68 \%$ and majority of the actors are unbanked. The level of MSMEs actors' financial literacy is important in business sustainability. This study aims to measure level of MSMEs financial literacy and determine its correlation with demographic and economic variables as well as designing models to increase the literacy. Results show that $51(25.5 \%)$ actors of MSMEs have low literacy level, 105 (52.5\%) have moderate level, and the rest of 44 $(22 \%)$ have high literacy level. Contingency Coefficient of $<0.6$ indicates that demographic and socioeconomic correlation is less strong in level of literacy. Result of analysis shows there are three factors forming the financial literacy model: first is financial attitude; second is financial knowledge, and the third one is financial behavior with the media used is face to face.
\end{abstract}

Keywords: MSMEs, Financial Literacy, Demographic and Economic Variables

\section{Introduction}

In both developed and emerging economies, promoting a favorable environment for the development of Micro, Small and Medium scale enterprises (MSMEs) is quite critical. MSMEs function as a primary driver for job creation and GDP growth. They greatly contribute to economic diversification and social stability and also play an important role for private sector development.

Strengthening and developing MSMEs which supported by financial resources will increase product competitiveness both in domestic and global market. The more competitive the superior products of the region, the tougher the MSMEs are and will create more job opportunities. It will also decrease the unemployment and in turn, increase the economic growth of regions.

MSMEs play an important role in Indonesian economy since $90 \%$ of economic actors are MSMEs. There are more than $99 \%$ of MSMEs in all firms of economic sectors and employ over $95 \%$ of the population (Aryco, 2017). MSMEs are always routinely involved in businesses decision making activities such as in determining resources allocation, investment, and saving. All these activities, most of which involve day to day business running, always have financial consequences for the entrepreneurs/businessmen. Therefore, effort is needed to enrich financial knowledge so that financial management can be accounted for. The company ability to recognize and access financial resources will have an impact on business sustainability (Adomako and Danso, 2016).

According to Braunstein and Welch (2002), level of family financial literacy correlates with the ownership of long-term savings, fulfillment of higher education and retirement funds. Ineffective money management will have an impact on family financial crisis. The findings can also be adapted for the company. In this case, MSMEs with good financial literacy will be able to achieve company goals, have business development orientation, and able to survive in difficult economic conditions. The low level of financial literacy can be a cause of many victims of financial crimes.

Financial literacy can be defined as the bulk of knowledge and cognitive capabilities necessary for managing and making effective

Received: September 03, 2017, Revision: September 05, 2018, Accepted: December 6, 2018

Print ISSN: 0215-8175; Online ISSN: 2303-2499. DOI: http://dx.doi.org/10.29313/mimbar.v34i2.2914.255-264

Accredited B based on the decree No.040/P/2014, valid on February, 18, 2014 until February, 18, 2019. Indexed by DOAJ, Sinta, IPI 
decisions regarding the handling of finances such as budgeting, bookkeeping, bills and utilities payments, loan acquisition and payments, and other financial decisions (Adomako, and Danso, 2016). Xiao (2008) views financial literacy as the knowledge of behaviors relevant and pertinent in money management which takes into consideration knowledge of income, money management, saving and investing, and spending and credit. According to Remund (2010), the operational definition of financial literacy is the possession of knowledge, skills, and trust to take responsible financial decisions. Thus, knowledge of finance is not sufficient for financial decision-making but still requires skill and confidence. While Gupta and Kaur (2014) state a definition of financial literacy as a combination of financial awareness, knowledge, skills, attitudes and behavior required in making the right financial decisions and will provide individual welfare. Financial literacy will provide knowledge relating to risk and return on the use of financial products and institutions (Bonte: 2012).

MSMEs are often confronted with financial constraints relating to access to financial institutions, capital resources, and limitations of saving. Hence, they frequently face problems of liquidity, credit schemes that unsuitable the needs, administrative requirements, interest rates and the guarantees (Prihartiningsih: 2012; Widiyati: 2014). MSMEs financial literacy level only reached $15.68 \%$ and majority of the actors are unbanked. This level of financial literacy is important in running the business as it is correlated with MSMEs performance (Dahmen and Rodriguez: 2014).

According to Kempson et al. (2005), financial literacy is related to behavior in four domains: (1) managing money; (2) planning ahead; (3) making choices; and (4) getting help. They conclude that financially capable people are (1) well organized, keep control over their financial resources; (2) able to deal with a large fall in income and unexpected events; (3) aware, confident and able to choose between the available financial products; (4) able to find and compare information for themselves and know where and when to turn for advice and help from a third party.

While Lusardi and Mitchell (2011) state that there are four principles need to be considered in order to measure level of financial literacy, which are simplicity, relevance, brevity, and capacity to differentiate. Indicators used to measure level of financial literacy are knowledge of interest rates, knowledge of inflation, and knowledge of risk diversification. While the indicators used by OECD (Organisation for Economic Cooperation and Development) in measuring level of consumer literacy are financial knowledge, financial behavior, and financial attitudes (Atkinson and Messy, 2012).

OJK (financial services authority) categorizes level of financial literacy of Indonesian people into four parts, namely (OJK, 2017) : first, well literate, that is, a person has knowledge and confidence of financial institutions and financial services products, including features, benefits and risks, rights and obligations related to financial products and services, as well as having skills in using them; second, sufficient literate, that is, a person has knowledge and beliefs of financial services institutions and financial products and services, including features, benefits and risks, rights and obligations related to financial products and services; third, less literate, is someone who has only knowledge of financial services institutions, financial products and services; and the fourth, non literate, that is, a person has no knowledge and confidence in financial institutions and financial products and services, let alone using financial products and services.

The success of MSMEs depends on their ability to manage financial issues. The higher the level of one's financial literacy, the better his/her financial management would be. Furthermore, Chinen and Endo (2012) and Jappelli and Padula (2011) say that individuals who have the ability to make right decisions about finance will not have financial problems in the future. They can show healthy financial behavior and be able to determine their priorities. A low level of financial literacy will result in a lack of access to financial institutions and hampered the success of economic development. Financial macro literacy is recognized as an essential element of stability and development necessary to create efficiency that plays an important role in the formation of financial system stability. Therefore, financial literacy will affect not only micro level (household) but also at macro level. Oseifuah, E.K. (2010), in his study find that the higher the level of financial literacy of the MSMEs owners, the better the performance of their businesses and the higher their chances to be succeed. From the above discussion, it is expected that business owners' financial literacy will positively influence the performance of their businesses. 
There is a vast array of empirical research that suggesting a strong correlation between financial literacy and household wellbeing. The results of Sheevun Di O. Guliman (2015) showed that in general, business actors have low level of financial literacy. This is indicated by their low knowledge of finance, taxation, budgeting and investment. Judging from the level of education, those in college are more financially literate than those of high school education and the length of the effort is negatively correlated with financial knowledge.

The study conducted by Kehiaian and Williams (2012) shows a positive correlation between financial literacy and financial education, work experience, income level, gender, and age. Thus, the demographic and socioeconomic variables correlate with the level of financial literacy (Lusardi, Annamaria, Mitchell and Curto: 2010; Shahnaz and Tabahani: 2013; Sarigul: 2014; Widiyati et al: 2017). Financial literacy level of MSMEs actors has an effect on the performance and business continuity. The research result of Fernandes (2015) shows a positive correlation between level of financial literacy and business performance. While the results of Novo Plakalovic study (2015) conclude that financial knowledge does not guarantee business success, but some other skills and abilities are a requirement to make the business better.

Considering the impact of MSMEs financial literacy to not only internal company but also wider scope of regional economy that hence study of financial literacy of MSMEs actors need to be done, the purpose of this research is to measuring level of financial literacy, linking the level of financial literacy to demography and social economy variable, and also designing model improvement of MSMEs financial literacy.

\section{Research Method}

The population in this study is MSMEs in Salatiga. According to Sekaran (2006), a sample size of more than 30 and less than 500 is appropriate for most studies. For a correlation study, the minimum number of samples to obtain good results is 30 . The number of samples taken in this study is 200 people. Sampling is done gradually by using purposive sampling method and sampling area. Purposive sampling is a sampling based on certain criteria so that the selected sample is relevant to the research design. The business unit sample selected has been operating for at least 3 years with a basic criterion of consistency. Samples of 50 business units are taken from each district (Salatiga consists of 4 subdistricts).

In this study, the data required are demographic and economic data of respondents (age, education, marital status, gender, income, length of business) and data related to variables studied. Methods of data collection are questionnaire and observation. The questionnaire is used to obtain primary data from selected respondents. It is designed with open and closed statement and/or question and is divided into two parts. The first part contains questions of respondents' profiles in view of demographic factors (gender, education, allowance, length of work), while the second part contains statements/questions relating to financial literacy and indicators of literacy determinant factors. Answers to questionnaire are provided in 5 alternative answers of Likert scale (scale 1 if the answer is strongly disagreeing and scale 5 if it is strongly agree). Second method is observation with the aim to see and observe directly the conditions and activities of respondents.

\section{Analysis Method}

Data analysis methods used are reliability and validity test, Chi-Square test, and Factoring analysis. A measure of reliability is assessed using Cronbach's Alfa test. It is a test used to measure the reliability of different categories and consists of estimation on how much variation in scores of different variables is attributed to chance or random errors. As a general rule, a coefficient greater than or equal to 0.6 is considered acceptable as a good indication of construct reliability (Ghozali: 2011). Validity is a measure that indicates the validity or validity of an instrument. An instrument is considered valid if it is able to measure or obtain the exact data of the variables studied. To measure the amount of variance of indicators extracted by latent construct developed, we can use the variance extract measurement. The high value of variance extracted indicates that the indicators have been well represented in the latent constructs developed. This minimum V.E value of 0.5. Chi-Square test (denoted by " $\mathrm{2} 2$ ") which used to test two groups of data both independent and dependent variables are categorical. In 
this case, it is used to test whether there is correlation between level of financial literacy and demographic and socioeconomic variables (age, education, marital status, gender, employment, turnover, length of business). Factoring analysis is essentially used to reduce data and summarizes a number of variables into fewer and named it a factor. The processes of factor analysis can be done in four steps. First, selecting the appropriate variable input factor analysis. Each variable must be correlated to each other and if the correlation is weak then it should be removed from the factor analysis by using MSA tool or Barlett's test. Second, the first step process resulted in multiple variables extracted into several variables. The popular factor search model is Principal Component and Maximum Likelihood. Third, if the content of factors are still doubtful, then the rotation is applied so that the factors formed are significantly different from others. Fourth, once the factors are actually formed, then the next process is naming them.

\section{Description of Respondents}

Table 1 reveals the descriptive statistics of social economic and demographic variables. The results show that most of the respondents are females, high school education, with their ages range from of 25-45 years old. Approximately, half of the respondents have businesses in the span of $\leq 3$ years -5 years. In addition, results showed that respondents' profits are in the range of $1-3$ million. Number of employees is an average of 3-6 people. Results also show that on the average, respondents' marketing area are local and outside the province. Majority of distribution is direct. More data can be seen in Table 1 .

Table 1

Description of Respondents

\begin{tabular}{llc}
\hline Description & & $\begin{array}{c}\text { A m o } \mathrm{u} \mathrm{n} \mathrm{t} \\
\text { (people) }\end{array}$ \\
\hline Gender & Male & 72 \\
& Female & 128 \\
Education & Secondary & 47 \\
& School & \\
& High School & 102 \\
& D3/Bachelor & 51 \\
& $<25$ years & 18 \\
Age & 25 -35 years & 46 \\
& 36 -45 years & 55 \\
& 46 -55 years & 24 \\
& 56 -65 years & 34 \\
& $>66$ years & 21
\end{tabular}

\begin{tabular}{lll} 
Business span & $<$ 3years & 47 \\
& $3-5$ years & 88 \\
& $>5-10$ years & 28 \\
& $>10$ years & 37 \\
& $<1$ million & 50 \\
& $1-3$ million & 86 \\
Profit/month & $>3-6$ million & 45 \\
& $>6-10$ million & 13 \\
Labor & $>10$ million & 6 \\
& $<3$ people & 56 \\
& $4-6$ people & 90 \\
& $7-10$ people & 40 \\
& $>11 \quad$ people & 16 \\
Marketing & Salatiga & 79 \\
& Central Java & 102 \\
& Outside & 19 \\
& Central Java \\
Distribution & Direct & 51 \\
& Indirect & 96 \\
& Combined & 53 \\
\hline
\end{tabular}

Source: Research Team 2017

\section{Correlation between Literacy Lev- els and Demographic and Economic Variables}

Financial literacy has become one of the focused policies of Government Agencies and Banking industries. There is a great concern that MSMEs tend the lack a working knowledge of financial concept. They do not have tools they need to make the best decisions in creating their better economic condition. Ineffective money management can also result in behaviors that make MSMEs more fragile to severe financial crisis.

Financial literacy of respondents can be categorized into three groups. First, the low level of financial literacy consists of respondents who are able to answer questions in maximum of four out of twelve questions. Second, level of moderate consists of respondents who are able to answer five to eight questions. Third, high level of financial literacy consists of respondents who can answer nine to twelve questions. The questions include savings requirements, interest concepts, and inflation. The results showed that 51 people $(25.5 \%)$ had low literacy rate, 105 people $(52.5 \%)$ had moderate literacy rate, and the rest 44 people (22\%) had high literacy rate.

The Pearson Chi-Square test is performed to prove whether there is a correlation between level of financial literacy and demographic variables (age, gender, education) and other predictor variables. 
Based on results of data processing, age, education, length of business, sales turnover, marketing, distribution channels, and number of labor have a correlation to the level of financial literacy. It showed that the coefficient of contingency between level of financial literacy and age, education, length of business, profits, marketing, distribution channels, and total labor is respectively $0.338 ; 0.214 ; 0.359 ; 0.530 ; 0.431 ; 0.305$; 0.343 and 0.340 . The level of correlation among variables is low. More data can be seen in the Table 2 .

Table 2

Pearson Chi-Squared and Contingency Coefficient

\begin{tabular}{|c|c|c|c|c|}
\hline \multirow{2}{*}{$\begin{array}{l}\text { Relationship } \\
\text { between } \\
\text { Financial } \\
\text { Literacy } \\
\text { Levels and }\end{array}$} & \multicolumn{3}{|c|}{$\begin{array}{l}\text { Pearson Chi- } \\
\text { Squared }\end{array}$} & \multirow[t]{2}{*}{$\begin{array}{l}\text { Contingency } \\
\text { Coefficient }\end{array}$} \\
\hline & Value & $d f$ & sig & \\
\hline Gender & 2.99 & 2 & 0.22 & 0.121 \\
\hline Age & 25.58 & 10 & 0.00 & 0.338 \\
\hline Education & 9.63 & 4 & 0.04 & 0.214 \\
\hline $\begin{array}{l}\text { Span of } \\
\text { Business }\end{array}$ & 29.67 & 6 & 0.00 & 0.359 \\
\hline Profits & 67.79 & 8 & 0.00 & 0.530 \\
\hline Marketing & 45.50 & 4 & 0.00 & 0.431 \\
\hline Distribution & 20.58 & 4 & 0.00 & 0.305 \\
\hline Labor & 26.15 & 6 & 0.00 & 0.343 \\
\hline
\end{tabular}

Source: Research Team 2017

\section{Validity Test}

The collected data is first tested with validity and reliability test. Validity test is conducted to 15 items statement as follows:

FK1: I understand the interest rate offered by bank; FK2: I understand the initial and final balance settled according to the terms; FK3: I know the requirements to use banking products; FK4: I understand the allocation of funds for banking products; FK5: I understand the time value of money.

FA1: Saving is important; FA2: Recording business cash flow is important; FA3: Separating business money and personal money needs to be done; FA4: Planning for the future is important; FA5: Expenditure should be based on priority scale.

FB1: Comparing prices before purchasing is important; FB2: Paying cash is cheaper; FB3: Recording monthly fees in the context of financial planning is important;
FB4: Setting up enough money for per-period of emergency is important; FB5: Saving some money for the future is important.

The test is intended to measure that the instrument used is appropriate. The measurement is done using Product Moment Correlation technique. The results of validity test can be seen in Table 3. Table 4 shows that all indicators is in a level of $<0.05$, which means the indicator is declared valid and can be processed for further analysis.

Table 3 Validity Test Result

\begin{tabular}{ccc}
\hline Indicator & Sig & Criteria \\
\hline FK1 & 0.000 & Valid \\
FK2 & 0.000 & Valid \\
FK3 & 0.000 & Valid \\
FK4 & 0.000 & Valid \\
FK5 & 0.000 & Valid \\
FA1 & 0.000 & Valid \\
FA2 & 0.000 & Valid \\
FA3 & 0.000 & Valid \\
FA4 & 0.000 & Valid \\
FA5 & 0.000 & Valid \\
FB1 & 0.000 & Valid \\
FB2 & 0.000 & Valid \\
FB3 & 0.000 & Valid \\
FB4 & 0.000 & Valid \\
FB5 & 0.000 & Valid \\
\hline & Source: Research Team 2017
\end{tabular}

\section{Reliability Analysis}

Reliability test is conducted to find out the existence of consistency. The technique used is Cronbach's alpha coefficient with the scores of $0.831,0.831$ and 0.832 . Based on the indicator, it is stated that if Cronbach's alpha is greater than 0.60 , it means the measuring tool can be trusted. The result shows that value of Cronbach is $>0.60$, which means it is reliable. The full results are shown in Table 4.

Table 4

Reliability Test Result

\begin{tabular}{|c|c|c|}
\hline Variable & $\begin{array}{l}\text { Cronbach } \\
\text { Alfa }\end{array}$ & Criteria \\
\hline FK & 0.831 & Reliable \\
\hline FA & 0.831 & Reliable \\
\hline FB & 0.832 & Reliable \\
\hline
\end{tabular}

\section{Factor Analysis}

This study further conducted factor analysis for data reduction. Factor analysis 
reduces a large number of correlated variables into a smaller one. In this study, factor analysis was conducted with data collected from field survey and aimed to simplify the determinants of literacy model which consisting of 15 statements into several factors. The simplification of this factor can be used to design model of financial literacy.

Bartlett's test is used to test the appropriateness of factor model. The summary of Kaiser-Meyer-Olkin (KMO) and Bartlett's test result is presented in table 6 . The KMO is a measure of sampling adequacy. The approximate chi-square statistic is 5183,346 with degree of freedom of 105 at the 0.05 -level significance. The appropriateness of factor analysis requires the KMO statistics to be ranging from 0.5 to 1 .

From the Table 5, it is observed that KMO Measure of Sampling Adequacy (MSA) is 0.799 which is more than the required value of 0.50 . It indicates that there is no error in $0.799(79,9 \%)$ of the sample, and in the remaining $20,1 \%$ there could be probability of error. Bartlett's test of sphericity indicates that the strength of the relationships among variables is strong. It presents good idea to proceed to factor analysis for the data.

Ho: There is significant indifference of all the designing model factors of financial literacy.
$\mathrm{H} 1$ : There is significant difference of all the designing model factors of financial literacy.

The value of Chi-Squared test 5183.346 (with significance level 0.00 ) signifies the rejection of null hypothesis. It means there is a significant difference between the designing model factors of financial literacy.

Table 5

KMO and Bartlett's Test

KMO and Bartlett's Test

\begin{tabular}{|ll|r|}
\hline Kaiser-Meyer-Olkin Measure of Sampling Adequacy. & .799 \\
Bartlett's Test of & Approx. Chi-Square & 5183.346 \\
Sphericity & df & 105 \\
& Sig. & .000 \\
\hline
\end{tabular}

Source: Research Team 2017

Communality of each statement refers to the variance being shared or common by other statements. The output comprises the communality of all 15 statements and the Eigen values of all variables having value of 1 or more than 1. In Table 7, the Eigen values for factors are, as expected, in decreasing order of magnitude as going from factor or component 1 to factor or component 15. Eigen value for a factor indicates the total variance attributed to the factor. The Eigen value for factor 1 , factor 2 , and factor 3 are sequentially

Total Variance Explained

\begin{tabular}{|l|r|r|r|r|r|r|}
\hline \multirow{2}{*}{ Component } & \multicolumn{3}{|c|}{ Initial Eigenvalues } & \multicolumn{3}{|c|}{ Extraction Sums of Squared Loadings } \\
\cline { 2 - 7 } & \multicolumn{1}{|c|}{ Total } & \% of Variance & Cumulative \% & \multicolumn{1}{c|}{ Total } & \% of Variance & Cumulative \% \\
\hline 1 & 5.545 & 36.968 & 36.968 & 5.545 & 36.968 & 36.968 \\
2 & 4.444 & 29.630 & 66.597 & 4.444 & 29.630 & 66.597 \\
3 & 3.484 & 23.228 & 89.826 & 3.484 & 23.228 & 89.826 \\
4 & .409 & 2.727 & 92.553 & & & \\
5 & .298 & 1.986 & 94.539 & & & \\
6 & .224 & 1.492 & 96.031 & & & \\
7 & .201 & 1.339 & 97.370 & & & \\
8 & .122 & .813 & 98.182 & & & \\
9 & .075 & .503 & 98.686 & & & \\
10 & .070 & .466 & 99.151 & & & \\
11 & .039 & .257 & 99.408 & & & \\
12 & .029 & .196 & 99.604 & & & \\
13 & .028 & .184 & 99.789 & & & \\
14 & .023 & .152 & 99.940 & & & \\
15 & .009 & .060 & 100.000 & & & \\
\hline
\end{tabular}

Extraction Method: Principal Component Analysis. 
$5.545,4.444,3.484$, which is more than the required level of 1 .

Factor 1 accounts for a variance of 5.545 which is $55.45 \%$ of the total variance. Factor 2 accounts for a variance of 4.444 , which is $44.44 \%$ of the total variance. Factor 3 accounts for a variance of 3.484 , which is $34.84 \%$ of the total variance. From the cumulative percentage column in table 7 , it can be concluded that the three factors extracted together account for $89.826 \%$ of the total variance. The variables have been reduced from 15 to 3 components or factors, while about $10.174 \%$ of information content will be lost.

\section{Rotated Component Matrix ${ }^{a}$}

\begin{tabular}{|l|r|r|r}
\hline \multirow{2}{*}{} & \multicolumn{3}{|c}{ Component } \\
\cline { 2 - 4 } & 1 & \multicolumn{1}{c}{2} & \multicolumn{1}{c}{3} \\
\hline FA3 & .967 & .091 & .033 \\
FA4 & .963 & .073 & .027 \\
FA1 & .962 & .105 & -.031 \\
FA5 & .959 & .058 & .004 \\
FA2 & .958 & .107 & -.022 \\
Fb3 & .077 & .952 & .095 \\
FB4 & .076 & .941 & .062 \\
FB2 & .078 & .937 & .022 \\
FB5 & .104 & .933 & .057 \\
FB1 & .089 & .906 & .096 \\
FK3 & -.016 & .072 & .966 \\
FK4 & -.004 & .067 & .951 \\
FK5 & .003 & .067 & .944 \\
FK2 & -.016 & .086 & .928 \\
FK1 & .040 & .036 & .874 \\
\hline
\end{tabular}

Extraction Method: Principal Component Analysis.

It is clear from the above table that variable of FA3; FA4; FA1; FA5 and FA 2 have loadings of $0.967,0.963,0.962,0.959$ and 0.958 , the highest for factor 1 . It suggests that factor 1 is a combination of those five original variables. Similarity for factor 2, it is a combination of variables FB3; FB4; FB2; FB5; FB1 with the loadings of 0.952, $0.941,0,937,0,933$ and 0.906 . Factor 3 is a combination of variables FK3, FK4, FK5, FK2, FK 1 and have loadings of $0,966,0,951$, $0,944,0,928,0,874$. Thus, factor 1 can be named as Financial Attitude, factor 2 can be named as Financial Behavior, and factor 3 as Financial Knowledge.

\section{Financial Literacy Model}

Every entrepreneur is a part of decisionmaking process related to acquisition, allocation, and utilization of resources. These processes have by nature financial characteristics. In order to act effectively, it is assumed that every entrepreneur has to be financially literate. It implies the ability to read, analyze, manage, and write about financial conditions of their businesses. Business continuity depends on business performance, one of which is related to finance.

Small business is the backbone of economy. When the financial literacy skills of entrepreneurs fall short of those needed to operate a successful business, it is more than the individual business at risk. Hence, failure to effectively and efficiently manage MSMEs would not only harm the individual business but could also negatively transcend to the aggregate economy. An entrepreneur is required to have financial intelligence. Financial intelligence is an intelligence associated with the proper management of financial assets that will provide optimal benefits and minimize the risk. Entrepreneurs are not only able to get but are also able to manage funds properly. Therefore, financial literacy is needed.

The level of financial literacy of MSMEs actors is important in running the business as this is correlated with the performance of MSMEs (Dahmen and Rodriguez: 2014). Financial literacy consists of financial knowledge and application of that knowledge in life. Factoring analysis shows three factors needed to increase financial literacy, which are Financial Attitude; Financial Knowledge, and Financial Behavior.

The results show that the average level of financial literacy is moderate. It means they understand the requirements to use savings and understand the concept of simple interest. The financial literacy correlates with age, education, length of business, sales turnover, marketing, distribution channels, and number of labor. The findings are not fully consistent with the empirical finds noted by Adomako and Danso (2016).

\section{Literacy Media}

According to Yuniati dan Yuningsih (2017), media literacy can be classified into two categories. First, it is based on the 
aimed media, and the second based on the proficiency level intended. Related to the media desired by respondents in financial literacy are as in the Table 6.

\section{Table 6 Literacy Media}

\begin{tabular}{ll}
\hline Media & Frequency \\
\hline Face to Face & 153 \\
Newspaper/Magazine & 65 \\
Brochures & 42 \\
Booklet & 68 \\
Social Media & 49 \\
Others & 45 \\
\hline
\end{tabular}

Source: Research Team 2017

The effort to improve the level of financial literacy could follow a systematic path. In order to formulate effective financial education model, the recommended model is in figure 1.

\section{Conclusion}

Financial literacy is a combination of financial awareness, knowledge, skills, attitudes and behavior required in making the right financial decisions and will provide individual welfare. The research presents an interesting and fascinating area for financial literacy and attempts to provide a deeper understanding of financial literacy level. The interaction occurred between level of financial literacy and demographic and economic variables. The study also finds factors that determine financial literacy model and media that needed for MSMEs literacy.

This research finding indicates that respondents are mostly women of high school education level with age ranged from 25 years to 45 years old. Viewed from the length of business, it was ranging from $<10$ years with a turnover from 1 million to 5 million and number of employees an average of 3-6 people. Marketing are mostly local and outside the province. The research also shows that respondents can be divided into three different groups regarding the level of financial literacy: low level of financial literacy consists of respondents who are able to answer questions with the maximum of four out of twelve questions, level of moderate financial literacy consists of respondents who are able to answer five to eight questions, and high level of financial literacy consists of respondents who can answer nine to twelve questions.

To prove whether there is a correlation between level of financial literacy and demographic variables (age, gender, education) and other predictor variables, then the Pearson Chi-Square test is performed. Based on the results of data processing, age, education, length of business, sales turnover, marketing, distribution channels, and number of labor have a correlation to the level of financial literacy.

The level of correlation between variables is low. The study also indicates that

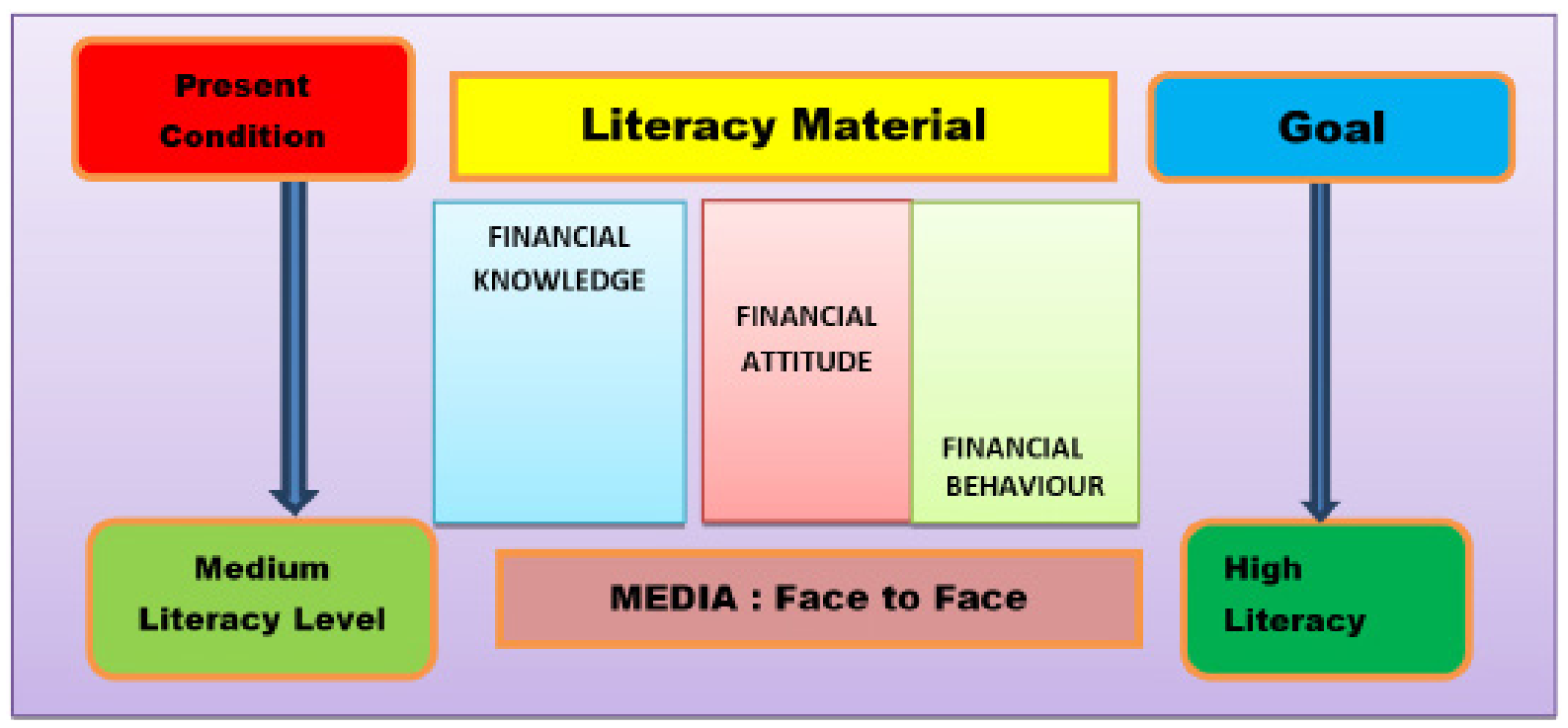

Figure 1. Financial Literacy Model 
financial knowledge, financial attitude, and financial behavior are important to design a financial literacy model. As a media, face to face is more effective than the others.

\section{References}

Adomako, S. and Danso, A. (2016). Financial Literacy and Firm Performance: The Moderating Role of Financial Capital Availability and Resource Flexibility. International Journal of Management and Organizational Studies, 3 (4), pp. 1-15.

Aryco, H. (2017). Peran UMKM Bagi Pereknomonian Indonesia. Diakses tanggal 22 November 2017 dari http:// www.internetmarketing.co.id/peran-bagiperekonomian-indonesia/

Atkinson, A., and Messy, F. (2012). Measuring Financial Literacy: OECD Publishing.

Bonte, W. A. (2012). Financial literacy, information flows, and caste affiliation: Empirical Evidence from India. Journal of Banking \& Finance, 36, 3399-3414.

Braunstein, S., and Welch, C. (2002). Financial Literacy: An Overview of Practice, Research, and Policy. USA: Federal Reserve Bulletin

Chinen, K., \& Endo, H. (2012). Effect of Attitude and Bacground on Personal Finance Ability: A Student Survey in the United State. International Journal of Management. (29).1: 33-45.

Dahmen, P., and Rodriguez, E. (2014). Financial Literacy and the Success of Small Businesses: An Observation from a Small Business Development Center. Numeracy: Advancing Education in Quantitative

Fernandes,T., I., M. (2015). Financial Literacy Levels of Small Businesses Owners and it Correlation with Firms' Operating Performance. Master in Finance Dissertation.

Ghozali,,I.(2011). Analisis Multivariate Lanjutan Dengan Program SPSS. Badan Penerbit Universitas Diponegoro. Semarang

Guliman, S., D., O. (2015). An Evaluation of Financial Literacy of Micro and Small Enterprise.Owners in Iligan City: Knowledge and Skills. $9^{\text {th }}$ Global Business Conference. De La Salle University, Manila, Philippines

Gupta, K., and Kaur, J. (2014). A Study of Financial Literacy Among Micro Entrepreneurs in District Kangra. International Journal of Research in Business Management. Vol 2, Issue 2, hal. 2347-4572.

Jappelli, T. and Padula, M. (2011). Investment in Financial Literacy and Saving Decisions. Papers Discussion 8220. Centre for Economic Policy Research.

Kehiaian, S. and Williams, A. (2012). Financial Literacy and Characteristics of Chapter 13 Debtors. International Journal of Business, Accounting, and Finance, 6(1),142-155.

Kempson E., Collards and Moore N. (2005). Measuring Financial Capability: An Exploratory Study. Financial Services Authority, Consumer Research Report no.37.

Lusardi, A. and Mitchell, O. (2011). Financial Literacy around the World: An Overview, Discussion Paper. Netspar Discussion Papers.

Lusardi, Annamaria, Olivia S. Mitchell, and Vilsa Curto.(2010). Financial Literacy among the Young. The Journal of Consumer Affair Vo.44,No.2.

OJK. Literasi Keuangan. Diakses tanggal 15 Oktober tahun 2017 dari https://www.ojk. go.id/id/kanal/edukasi-dan-perlindungankonsumen/Pages/Literasi-Keuangan.aspx

Oseifuah, E.K. (2010). Financial literacy and youth entrepreneurship in South Africa, African Journal of Economic and Management Studies, 1(2), pp. 164-182.

Plakalovic, N.(2015). Financial Literacy of SMEs Managers.International Conference

Prihartiningsih, Widiyati, S., Rois, M. (2012). Model Penguatan Kapasitas Kerajinan Logam dan Suku Cadang Mesin Untuk Meningkatkan PAD Kabupaten Tegal. Hasil Penelitian yang tidak dipublikasikan

Remund, D., L. (2010). Financial Literacy Explicated: The Case of Clearer Definition in an Increasingly Complex Economy. The Journal of Consumer Affairs.

Sarigul, H. (2014). A Survey og Financial Literacy Among Univercity Student. The Journal of Accounting and Finance.

Sekaran, U. (2006). Metodologi Penelitian Untuk Bisnis.Salemba Empat.Jakarta

Shahnaz, N, and Tabani,, M., S. (2013).The Impact of Financial Literacy on Individual Saving:An Exploratory Study in The Malaysian Context. Transformation in Business and Economics, Vol 12 (no.1) 28.

Widiyati, S. (2014). Peluang Koperasi Dalam Pengetasan Kemiskinan. Jurnal Keuangan dan Bisnis. Vol 1 no. 1.

Widiyati,S, Fatati, Manarotul, Listiyani,Tyas. (2017). Peningkatan Literasi UMKM Batik di kota Salatiga. Laporan Penelitian tidak 
dipublikasikan.

Xiao, J.J. (2008). Handbook of Consumer Finance Research. Ed. New York, NY: Springer.
Yuniati, Y., Yuningsih, A.(2017). Utilization of Smartphone Literacy in Learning Process. Mimbar: Jurnal Sosial dan Pembangunan, Vol. 33, No.1, hal. 90-98. 